\title{
Exploration of Full-time Professional Degree Graduate Training Mode Relying on Enterprise Workstation of Graduate Student
}

\author{
Jiyang Qi*, Lingyun Wang, Feifei Liu \\ School of Mechanical Engineering , Jiangsu University of Science and Technology, \\ Zhenjiang,212003,China \\ E-mail: jyqi@just.edu.cn;945083021@qq.com;1449689495@qq.com

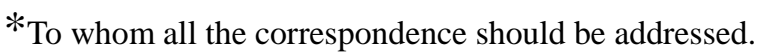

\begin{abstract}
In order to meet the demands of economic and social development, China will develop postgraduate education for professional degree on a large scale. By virtue of successful experience in the construction of post-doctoral workstation, the Education Department of Jiangsu Province has established some graduate students' workstations in large and medium-sized enterprises in Jiangsu Province to enhance the graduates' engineering ability in practice relying on workstation of business graduate student. From the following five aspects, the transformation of the concept of university teachers, enhancing the enterprise's ideology to share in social responsibility for education, strengthening the understanding of the importance of practical ability for graduate students, the division of labor and corporation between school instructors and corporate mentors and dissertation, this paper analyzes how to improve the quality of graduate education and to promote healthy development of graduate education relying on enterprise postgraduate workstation.
\end{abstract}

Key words-Full-time professional degree graduate students; Workstation of business graduate student; Engineering Practice Ability

\section{DEVELOPING THE PROFESSIONAL DEGREE GRADUATE EDUCATION ON A LARGE SCALE TO MEET THE DEMANDS OF SOCIAL AND ECONOMIC DEVELOPMENT}

It has been more than 30 years since the resumption of the postgraduate enrollment system in 1978. According to “Academic Degree Rules of People's Republic of China” passed in 1980, the educational objectives for postgraduates are as follows: mastering solid theoretical foundation and systematic knowledge of the special line about their major and having the ability to undertake scientific research or independently to engage in a special technical work. The harmful trends of emphasizing on knowledge not ability, and theory not practice is ubiquitous for postgraduate education institutions in the process of cultivating postgraduate[1]. The cultivating model of positioning postgraduate as academic professional talents is fit for planned economy system in $20^{\text {th }}$ century and the main tendency of postgraduates' employment in colleges and universities and scientific research institutions. This mode has cultivated a large number of high-level scientific talents which were in desperate need for colleges and universities and scientific research institutions.

With the rapid development of economy and society in China, there is an urgent need for a large number of high-level talents with innovation ability, entrepreneurial ability and practical ability. With the increased postgraduate enrollment and ever-changing social requirement, postgraduate are mainly engaged in product research and development work in factories not teaching and research work in colleges and universities and scientific research institutions. In this circumstance, the old single training model of positioning postgraduate as academic professional talents was not adopted to the social development. Postgraduate education institutions and faculty advisers must change ideas and strengthen the cultivation of postgraduates' practical ability.

Professional degree education has focused on those people with certain working experience to meet their need of continuing education without abandon their job since it was set up in 1991. Over more than 20 years of development, the variety of professional degree education is become more and more, the scale is becoming larger and larger and the influence is becoming greater and greater. It plays an important role in cultivating high-level applied specialized personnel[2]. However, compared with urgent needs of country economic construction and social development for high-level applied specialized personnel, it is relatively small-scaled. In that case, Ministry of Education made a decision that postgraduate education is practice-oriented and introduces "full-time professional degree graduate" as a new type of master. Moreover, schools will enroll more full-time professional degree graduate largely from graduating student since then. What's more, it has started to reduce ratio of academic graduate to increase that of full-time professional degree graduate, and finally, it will realize a goal of full-time professional degree graduates for $70 \%$ and academic masters for $30 \%$. Full-time professional degree graduate education focuses on raising graduate's ability of engineering study for the enterprise, while academic graduate education centers on those students who will pursue further doctorial study and devote themselves to scientific research to meet the need of colleges and universities and scientific research institutions.

Ministry of Education has made the decision that more postgraduates will receive professional degree graduate education, professional scope will be broadened and professional degree graduate education is to cultivate applied talents. With the rapid development of economy and society, there is an urgent need for high-level applied talents. Postgraduate education needs to actively adjust itself. The decision is an effective way to solve postgraduates' shortage of practical ability. It is also a popular form adopted by developed countries in the process of cultivating postgraduate. It can lessen the contradiction between vigorous demand for high-level applied talents for 
enterprises and shortage of high-level applied talents in the process of education.

\section{THE DECLARATION AND CONNOTATION OF} ENTERPRISE WORKSTATIONS OF GRADUATE STUDENT

A. Feasibility and necessity of establishment of enterprise workstations of graduate student

Since the first expansion of enrollment in postgraduates in 2000, the number of postgraduates has been increasing gradually. In 2005, the number of postgraduates surpassed 1 million. The scale of Chinese graduate education ranks only second to America. At the same time, we clearly notice that graduate educational quality is worrying. Whether from the perspective of international comparison, or from the perspective of the training process, in all kinds of quality indexes, our graduates' practical ability is obviously lousy [3].

As a result of the fast expansion of the scale of graduates it is difficult to meet the demands of graduates for practice when only depending on resources of postgraduate education institutions. Nevertheless, enterprises have the most advanced production equipment and manufacturing technology, real engineering environment and experienced engineers, which colleges and universities don't have, therefore, enterprises should play the role of cultivating graduates, especially full-time professional degree graduate.

In order to improve the quality of postgraduate training, to promote such innovative elements as talents to gather in the enterprise, with reference to the successful experience of enterprise post-doctoral research workstation, Department of Education in Jiangsu province has begun to set up workstation of graduate student in enterprises so that graduate students have an opportunity to work in enterprise workstation of graduate student and participate in enterprises' actual project for a year or so. This practice helps to consolidate and enhance their level of knowledge and research capacity. It also helps to enhance their skills to solve practical problems of enterprises and opens a real way to future employment and success.

On the other hand, in order to become bigger and stronger, in addition to the need to strengthen their research strength, enterprises also need external scientific and technological strength to support R\&D of its new products, new processes, and new technologies. And enterprises hope that external scientific and technological strength can help to analyze and solve the problems of production quality [4]. Through setting up workstation of business graduate student and letting graduates participate in the R\&D and production, enterprise researchers and graduates can enhance their research capacity in the collaborative process. Besides, enterprises' technical problems can be solved at a lower cost.

\section{B. Properties and duties of enterprise workstations of graduate student}

Enterprise workstation of graduate student is set up by enterprises and it is also funded by enterprises. Some research is conducted in the enterprise workstation by the postgraduates supervised by graduate tutors. It is an important platform for university-industry cooperation and is an innovation practice base for cultivating graduates[5].

Enterprise Workstation of graduate student is responsible for two important tasks. One is personnel training, and the other is enterprises' technology R\&D. Companies which have set up workstation of graduate student should provide graduates with corporate mentors and assist the guidance of school mentors. Enterprises should actively create the atmosphere of encouraging innovation and tolerating failure for graduates so that graduates can boldly participate in research projects at the workstation. Graduates should take full advantage of their professional expertise to help enterprises overcome technical problems. Graduates can not only complete $\mathrm{R} \& \mathrm{D}$ tasks, but also carry out leading-edge, innovative and theoretical research projects.

\section{MEASURES TO IMPROVE THE TRAINING QUALITY OF PROFESSIONAL DEGREE POSTGRADUATE}

A. Building the ideology that postgraduate students are application-oriented, and fully understanding the important role of enterprises in the process of cultivating postgraduates

Graduate instructors and graduate students must be keenly aware that a growing number of graduates are employed in the enterprises to work on applied work since the substantial enrollment expansion of graduates since 2000. In this case, it will no longer meet social demands for talents if still using the past training mechanism of graduate student to cultivate large-scale graduates. The goal of the past training mechanism is to cultivate lead-edge scientific talents [6]. Therefore, China actively adjusts the structure of graduate cultivation type, changing past graduate education from academic-oriented to application-oriented[7]. This is an inevitable choice for Chinese graduate education to meet the needs of the society.

For the realization of the changes of graduate cultivation type, graduates' research project and training programs must come from practice, and be as consistent as possible with the needs of enterprises and industry. Therefore, the training of graduate students has become a systematic engineering. In the process of graduate training, colleges and universities need to focus on recruitment and use of social resources, to strengthen cooperation with enterprises. Through establishing graduate student workstation, product R\&D center, laboratories and other forms with enterprises, colleges and universities build a teaching platform for graduates' practice, taking full advantage of the most advanced production equipment and manufacturing technology, real engineering environment and experienced engineers, etc., which colleges and universities don't have. They establish the training mechanism for graduates between universities and enterprises. Universities and enterprises complement each other. The theoretical knowledge and engineering practice mix together [8]. Consequently, graduates' ability of application, innovation and practice is cultivated. Graduates can meet social demands for high-level applied talents. 


\section{B. Enterprises should strengthen social responsibility of developing higher education and participate in the construction of graduate workstations not for the purpose of profit}

For their own survival, it is certainly understandable for enterprises to pursue profit maximization. But entrepreneurs must be aware that they must take into account social responsibility when they pursue corporate profit maximization. Enterprises can participate in education through donation, co-building laboratories, and establishing training bases, and so on. This is not only a behavior to fulfill social responsibility, but also can help enterprises gain advantages in fierce global competition. Microsoft, IBM, Oracle Corporation, etc., are good examples.

Graduate student workstations will inevitably require a certain amount of capital investment and human resources investment. And the impact on the growth of the economic efficiency of enterprises cannot be quickly apparent. Under this circumstance, enterprises should recognize the creativity of graduates, the advantage of establishing graduate student workstation. Graduate student workstation can help enterprises to understand new technologies at home and abroad, to strengthen cooperation with colleges and universities, to recognize the opportunities of technological innovation brought by graduate student workstation. Graduate student workstation also has a positive effect on long-term development.

Graduates who are working in graduate workstation have a wealth of theoretical knowledge, but most of them lack the experience of product $R \& D$ and firstly participate in research activities. Therefore, in the process of product $R \& D$, there will be all kinds of problems, even failure. Enterprises should be tolerant of their failure and create a relaxed human environment. They should encourage graduates to be bold in practice. If enterprises only emphasize on success, it will inevitably cause their worries so that they do not dare to innovate and explore, be unwilling to innovate.

Enterprises should treat graduates who are working in graduate student workstation with a responsible attitude. Enterprises should care for them not only in works, but also in daily lives. It is not desirable for enterprises to treat graduates as cheap labor for the purpose of immediate interest. Graduates should not be engaged in low-tech labor. Enterprises must avoid the wrong tendency of focusing on use not training.

\section{Graduates should fully understand the importance of practical ability and actively participate in graduate student workstation}

Graduates should be fully aware of social increasing demands for practical ability of graduates. It is an inevitable trend of postgraduate training that graduates are employed in enterprises. Graduates work in real production environment in enterprises. It will help to find their interests, traits of character, competencies and the shortage of knowledge, to stimulate occupational psychology and professional dedication, to enhance their ability of adapting to society, interpersonal exchanges and adaptability[9].
Enterprises have a strict system of working hours. Graduates should strictly comply with work and rest regime. Graduates mustn't think they can turn a deaf ear to the rules and regulations of enterprises because they are not full-time employees. Graduates should keep trade secrets from wrongful appropriation and protect the interests of enterprises.

When working in enterprise workstation of graduate student, graduates should be humble and get along with engineers and workers. Technical personnel and workers may be short of theoretical knowledge, but they have a wealth of practical experience which graduates should learn.

When working in enterprise workstation of graduate student, graduates should be actively involved in product R\&D activities, using their knowledge to help enterprises solve problems and make contribution to the development of enterprises. Through being involved in product $R \& D$ activities, graduates can combine theoretical knowledge with practice. It not only helps enterprises improve services, but also helps them accumulate experience and absorb new knowledge and skills. It is a win-win situation for enterprises and graduates.

\section{Corporate tutors and school mentors cooperate with each other, performing their own functions}

The role of mentors is important in the process of postgraduate education. In order to give consideration to academic level and practical ability of postgraduates, most schools carry out school- and-enterprise double tutorial system, that is to say, providing graduates with supervisor group consisting of school mentors with academic background and corporate tutors with extensive practical experience.

The teaching jobs of school mentors are teaching graduates to do academic research. Their academic background, academic accomplishment and academic training cause the shortage of practice[10]. However, corporate tutors have the characteristics of high sociality, excellent practical ability and being a good example. They are strong complements to school mentors. Therefore, when emphasizing on the leading role of school mentors, we should also pay attention to the directive function of corporate tutors. In order to enhance graduates' comprehensive quality, school mentors and corporate tutors should regularly have face to face communication, mutual cooperation. They should learn from each other to fulfill their duties.

When carrying out school-and-enterprise double tutorial system, each instructor should understand their own responsibilities. School mentors are mainly responsible for training quality in the process of cultivating graduates. Corporate tutors mainly assist school mentors and provide graduates with research facilities and platform. Corporate tutors focus on enhancing graduates' innovation and practical ability. School mentors and corporate tutors exploit their own strengths, learning from each other and sharing the important task of cultivating high-quality applied talents.

University teachers are clearly aware that training graduates is their main responsibility, so they can take the 
responsibility of guiding graduate seriously. Corporate tutors focus on enterprises, so it is liable for corporate tutors to ignore their responsibilities of tutors. Therefore, corporate tutors' enthusiasm and initiative should be enhanced. When choosing corporate tutors, we should take the strong sense of responsibility as one of the important criteria. In addition, with reference to undergraduate teaching supervision regulations, there should be graduate teaching supervision regulations. We should regularly inspect the supervision and guidance of tutors, especially corporate tutors, to enhance the supervision for graduates[11].

\section{E. Dissertation topics should come from practice and be higher than practice}

Dissertation topics are the starting point of researching work and an important part of training creative thinking and research capacity. It is the key to improve the quality of papers. There will be high-quality papers on the premise that there are high-quality dissertation topics.

The object of study of graduates is the practical problems in the process of production. These problems focus on applicability and often don't need theoretical research. It is often the case that they cannot be researched deeply. If we merely choose practical problems as dissertation topics, it will cause the lack of theoretical depth and cannot meet the demands of "Degree Law of the People's Republic of China”. However, if dissertation completely breaks away from practical problems, it will cause that graduates are busy with their papers and are not involved in $\mathrm{R} \& \mathrm{D}$ of products. That situation is contrary to the original intention of upgrading graduates' practical ability with the help of enterprise workstation of graduate student.

Therefore, when choosing the topics of graduate papers, graduates must adhere to the dissertation principle of master's degree thesis. Under the premise of fully considering the actual needs of production, graduates should selectively do in-depth research on certain issues to extract high-quality dissertation [4]. Thus, dissertation should come from practice and be higher than practice. Graduates' research works not only help enterprises solve immediate practical problems, but also provide reference for long-term development of enterprises. On the one hand, graduates improve their ability to resolve actual production problems. On the other hand, graduates strengthen the understanding of the subject of key technologies.

\section{SUMMARY}

In order to meet the needs of economic and social development, Ministry of Education adjusts the positioning of graduates and gradually increases the enrollment ratio of full-time professional degree graduate. The key of education of professional degree graduate is to enhance their engineering practical ability. Enterprise workstation of graduate student is the holy trinity -society, universities and graduates. It strengthens the cooperation between universities and high-tech enterprises. Relying on workstation of business graduate student, postgraduate education institutions are trying to cultivate graduates' scientific innovation ability and engineering practice ability.
The cultivation of graduates with the deep participation of enterprises is bound to have a positive effect on improving graduates' quality.

\section{REFERENCES}

[1] Huang Jing, Huang Zhengquan. Systematic Comparison of Cultivating Model of Master Student between China and America[J]. Journal of Technology College Education, 2005,24(4):34-36

[2] Ministry of Education, People's Republic of China. Some Opinions about How to Cultivate Full-time Professional Degree Master.

[3] Fu Weili, Chen Jingjing. Research on Cultivating Model of Practical Ability of Foreign Students[J]. Education Science,2005,21(1):52-56

[4] Qian Yiyu, He Peng. Teaching Practice and Thoughts on Cultivating Applied Master Student Base on "Production-Learning-Research" [EB/OL].http://news.hit.edu.cn/articles/2010/01-21/ 01152503.htm

[5] Department of Education, Jiangsu Province. Regulations of Enterprise Workstation of Postgraduate Students in Jiangsu(on trial). 2008

[6] Deng Yan. Discussion about Enterprise Workstation of Postgraduate and Reform of Cultivating model of Postgraduate Student[J]. Times of Chinese, Education of China and Foreign Country, 2011,(1)

[7] Regulate the cultivating orientation of Master Student in China Application-oriented, Pursing Three Certificates [N]. People’s Daily, 2011-1-16(02)

[8] Lu Yin, Song Jianxin, Deng Yan, etc. Practice of Construction of Enterprise Workstation Full-time Professional Degree Master Student. Scientific Information. 2010，（35）:8

[9] Zhang Li, Chen Xi. Upgrade the Comprehensive Ability of Mater Student Based on Workstation of Postgraduate Students[J]. Beijing Education(Higher Education Version) .2010,(4):58-59

[10] Chen GUgang, Chen Xiumei. The Viewpoints of quality of education of Professional Degree Master. Academic Degrees \& Graduate Education,2006,(7):28-32

[11] Exploration of Cultivating Model of Full-time Professional Degree Master Supervised by dual-tutors[EB/OL].http://www.cglunwen.com /lunwen/20111021/2635.html 